\title{
The Effect of Bacillus Coagulans and Moulding Water Content on the Unconfined Compressive Strength of Lateritic Soil
}

\author{
Paul Yohanna $^{1^{*}(\mathbb{0})}$, Eberemu Adrian Oshioname ${ }^{2}{ }^{(}$, Thomas Stephen Ijimdiya $^{3}$, Kolawole Juwonlo \\ Osinubi $^{3}{ }^{\circledR}$ \\ ${ }^{1}$ Department of Civil Engineering, University of Jos, Plateau State, Nigeria \\ ${ }^{2}$ Department of Civil Engineering, and Africa Center of Excellence on New Pedagogies in Engineering Education, Ahmadu Bello \\ University, Zaria, Kaduna State, Nigeria \\ ${ }^{3}$ Department of Civil Engineering, Ahmadu Bello University, Zaria, Kaduna State, Nigeria \\ Email: paulyohanna45@yahoo.co.uk
}

Received: 13 December 2021; Revised: 8 January 2022; Accepted: 17 January 2022

\begin{abstract}
The effect of bacterial concentrations of Bacillus coagulans and moulding water content (MWC) on the unconfined compressive strength (UCS) of lateritic soil for use as waste containment material was studied. Tests conducted include index test, $\mathrm{pH}$, calcium carbonate content (CCC), and UCS. Soil samples for all tests were mixed with an increasing number of microbes at step suspension densities of 0 up to $2.4 \times 10^{9}$ cells $/ \mathrm{ml}$ individually. The soil was prepared at MWC of $-2,0,+2$, and $+4 \%$ in relation to optimum moisture content (OMC) and compacted using the Reduced British Standard Light (RBSL), British Standard Light (BSL), West African Standard (WAS) Compaction and British Standard Heavy (BSH) Compaction Energy (CE) respectively. The cementation reagent was added to the compacted samples and allowed to flow by gravity to a point that saturation was reached. Results revealed an increase in $\mathrm{pH}$, while calcium carbonate content values marginally increased from $3.6 \%$ at the natural state to $3.9 \%$ maximum value at $2.4 \times 10^{9} \mathrm{cells} / \mathrm{ml}$. The UCS values increased with a higher number of microbes. Values increased from 204.6, $278.3,351.3$, and $416.8 \mathrm{kN} / \mathrm{m}^{2}$ for the natural soil to peak values of $1,036.3,1,835.5,2,076.8$, and $2,237.3 \mathrm{kN} / \mathrm{m}^{2}$ for specimens prepared at $-2 \%$ OMC and compacted with RBSL, BSL, WAS and BSH compaction energy, respectively. A similar trend was observed for $0,+2$, and $+4 \%$ in relation to OMC. A minimum regulatory UCS value of $200 \mathrm{kN} / \mathrm{m}^{2}$ was achieved at MWC of $-2,0$, and $+2 \%$ OMC for all energies. Therefore, it is recommended that CE, moisture content, and the number of microbes should be carefully studied during field construction of a lateritic soil-compacted clay liner in other to achieve the desired result.
\end{abstract}

Keywords: B. coagulans, compaction energy, compacted clay liner, lateritic soil, MICP, unconfined compressive strength

\section{Introduction}

Lateritic soils are coloured reddish or reddish-brown tropical soils freely available in Nigeria and other nations [1], [2]. These soils in their untreated states in many cases are not good enough for use as construction materials because of their relatively high fine content, high water absorption, swelling and shrinkage problems during wetting and drying,

Copyright (C2022 Paul Yohanna, et al.

DOI: https://doi.org/10.37256/est.3120221286

This is an open-access article distributed under a CC BY license

(Creative Commons Attribution 4.0 International License)

https://creativecommons.org/licenses/by/4.0/ 
excessive cracking when dry, etc. Thus, this necessitates the requirement for improving such category of soils, to meet the engineering needs for construction or other engineering uses. The practice of using additives produced from industries like cement, lime, bitumen and the use of industrial and agro waste with pozzolanic potentials has proven to be successful in improving the engineering performance of such deficient lateritic soils [3]. However, the application of these techniques is either costly or not environmentally pleasant and for that reason non-viable [4].

The need for a sustainable mechanism for improving soil is necessary to meet the engineering requirement of deficient soils. A new, sustainable, and environmentally welcoming approach to soil improvement is termed Microbial induced calcite precipitation (MICP). MICP is one of the evolving soil improvement practices. MICP process involves bonding the soil particles and thus enhances the performance of soil. This practice is achieved by the use of ureaseproducing bacteria that releases urease enzyme to catalyze urea to carbonate and whose end products result in calcite precipitation in a high $\mathrm{pH}$ environment. The MICP method is faced with the problem of non-uniformity of calcite precipitation and inadequate penetration depth of the microbes in the modified soil, which hinders the use of this stateof-the-art soil improvement technology [5], [6]. Non-uniformity of calcite precipitation has been a major challenge in MICP as a method of soil improvement as reported in pieces of literature [6], [7], which include among many the flow rates through the soil medium being too fast to allow for reaction to take place, insufficient quantity of nutrient provided, or nutrients being exhausted over time. Even though the method has some demerits, it is a green and also sustainable system of soil improvement [6].

Several investigations had reported positive results on the use of MICP in many engineering uses such as waste containment application [4], [8], soil stabilization for road construction purposes [9], concrete works [10] and so on. Chi et al. [11] conducted a study on Aeolian sand to aid in mitigating soil erosion. The study provided evidence of improvement in the soil strength by an increase in UCS values and other soil properties with the aid of the MICP method. Adharsh et al. [12] outlined several beneficial uses of MICP in diverse engineering fields. The friendly and sustainable characteristics of this approach were also discussed. The application of MICP at a large scale still has some bottlenecks that are yet to be overcome such as reliance on $\mathrm{pH}$, temperature, calcium concentration, availability of nucleation sites [12], [13]. Notable applications of MICP with respect to soil improvement and in concrete applications has also been reported in several articles [4], [8], [14]-[19].

The impact of moisture variation within the soil matrix at different compaction densities cannot be underestimated as it affects the structural strength and stability of the soil. Moisture variation in the soil makes it necessary to simulate such behaviors using small-scale experiments prior field trials. The relative effect of moisture changes within the treated soil at different compaction densities was studied. A previous study [4] reported on only one compactive effort. The need to study varying compaction conditions is important to accommodate all changes for convenient field application. Therefore, this work focuses on the evaluation of changes in the UCS of lateritic soils using a green MICP technique that involves soil improvement with a varying number of microbes (cells $/ \mathrm{ml}$ ). The specific objectives of the study include the determination/changes in UCS with a varying dosage of microbes and MWC of the soils and statistical study of the results.

\section{Materials and methods}

\subsection{Materials}

\subsubsection{Soil sample}

The reddish-brown lateritic soil was collected using disturbed sample technique from Abagana $\left(68^{\circ} 24^{\prime} 31^{\prime \prime} \mathrm{N}\right.$ and $\left.27^{\circ} 52^{\prime} 11^{\prime \prime} E\right)$, South-East of Nigeria. The collected sample was allowed to dry under the sun in the open air, crushed before sieving through a $4.76 \mathrm{~mm}$ sieve aperture (BS No. 4 sieve). Samples were kept away from moisture throughout the test in the laboratory.

\subsubsection{Microorganism}

The microorganism utilized in this study is B. coagulans, classified as ATCC 8038 [19]. Bacillus coagulans was isolated from the soil used in the study. It is a gram-positive bacterium. It forms a spore around its body to protect from adverse conditions and remain inactive within those periods. 


\subsubsection{Cementation reagent}

The cementation reagent used encompassed $3 \mathrm{~g}$ of Nutrient broth, $20 \mathrm{~g}$ of urea, $10 \mathrm{~g}$ of $\mathrm{NH}_{4} \mathrm{Cl}, 2.12 \mathrm{~g}$ of $\mathrm{NaHCO}_{3}$, and $2.8 \mathrm{~g} \mathrm{CaCl}_{2}$ per litre of distilled water as defined by Stocks-Fischer et al. [20].

\subsubsection{Bacteria solution}

Solution of the Bacteria (B. coagulans) used for the processes of inoculation comprise of $3 \mathrm{~g}$ of Nutrient broth and $20 \mathrm{~g}$ of urea per litre of distilled water.

\subsection{Methods}

\subsubsection{Bacterium isolation}

The process of microbial Isolation from the soil was achieved through the technique of serial dilution [4]. The storage of the isolates was done at $4{ }^{\circ} \mathrm{C}$.

\subsubsection{The culture medium and growth conditions}

The approach applied was defined by Stocks-Fischer et al. [20].

\subsubsection{Soil sample preparation}

Soil treatment was carried out for varying Bacterial suspension at one-third pore volume as specified by Rowshanbakhta et al. [5]. The first one-third pore volume (i.e the numerical difference between the initial degree of saturation before soaking in water and final degree of saturation after full saturation of the soil specimens in water) of the bacterial solution was added to a given quantity of water and mixed properly as shown in Figure 1. The mixture is then mixed thoroughly with the soil sample as shown in Figure 2. Samples were then compacted in a mould before the application of the cementation reagent.

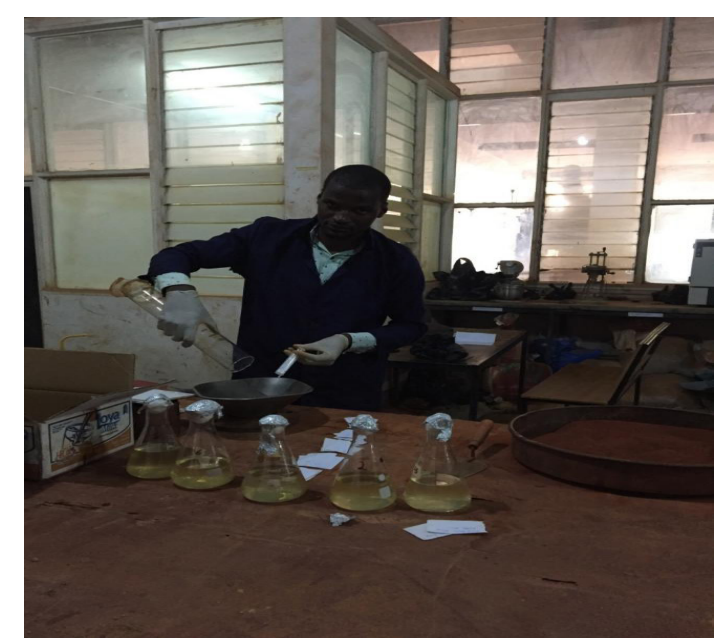

Figure 1. Mixing of bacterial solution with water

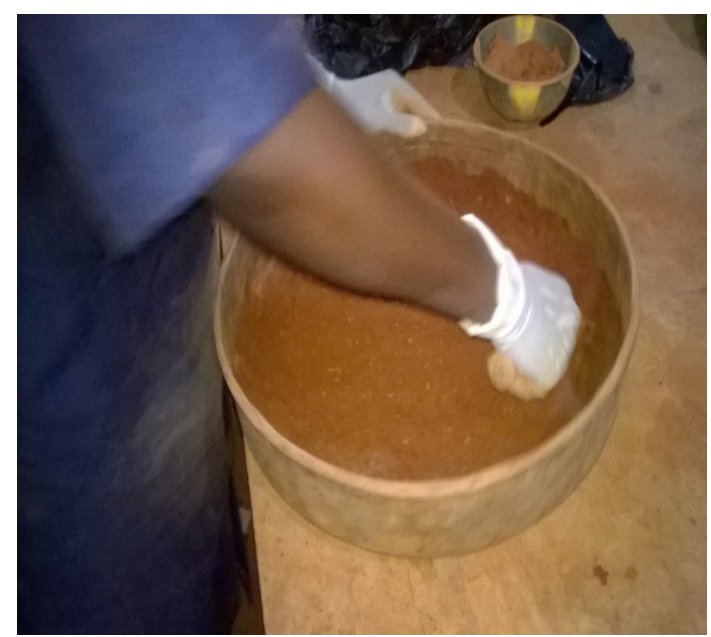

Figure 2. Mixing of soil with the mixtures at one-third pore volume

\subsubsection{Unconfined compressive strength}

The UCS test was achieved based on the specification mentioned in BS 1377; 1990 part (7) [21]. Soil samples were mixed before compaction with varying no of microbes prepared at one-third (1/3) pore volume (based on the suggestion of Rowshanbakhta et al. [5]). Preparation of sample was done at MWC of $-2,0,+2$, and $+4 \%$ in relation to OMC and 
compacted using RBSL, BSL, WAS, and BSH compaction energies. Application of Cementation reagent was done after compaction and allowed to flow by gravity, to a point when saturation was reached. The samples were cured for 48 hours. After curing, the samples were positioned in a load frame machine then tested. The UCS was calculated using equation 1.

$$
\sigma=\frac{R \times C_{r} \times(100-\varepsilon \%) \times 1000 k N / m^{2}}{100 \times A_{0}}
$$

Where:

$$
\varepsilon \%=\frac{v}{L_{0}}
$$

$\varepsilon \%$ is the strain percent, $v$ is the amount of deformation $(\mathrm{mm}), R$ is the load ring reading determined at strain $\varepsilon, C_{r}$ is the calibration of load ring, $L_{0}$ is the initial specimen length before testing $(\mathrm{mm})$, original cross-sectional area, $A_{0}\left(\mathrm{~mm}^{2}\right)$ and $\sigma$ the compressive stress $\left(\mathrm{kN} / \mathrm{m}^{2}\right)$.

\subsection{5 pH test}

The test for $\mathrm{pH}$ was achieved by collecting a small portion of samples prepared for the UCS test mixed at OMC. Compactions of the samples were done at BSL energy. Samples used for the pH test were taken at the uppermost and lowermost point of each compacted sample in the mould. The $\mathrm{pH}$ test was carried out using a $\mathrm{pH}$ meter.

\subsubsection{Calcium carbonate test}

\subsubsection{Sample preparation}

The calcium carbonate content (CCC) test sample was prepared similar to that of the $\mathrm{pH}$ test discussed above. CC test was done as proposed by Mortensen et al. [22] and Choi et al. [23] termed the acid wash technique. This washing technique is capable of removing all soluble calcium in the soil. At that point, the remaining solid particles retained on the sieve were dried in an oven and then measured to determine their mass. The mass change between the initial soil sample (A) and post washing sample (B) is the mass of CCC. Using equation 3.

$$
C C C=100-\frac{B}{A} \times 100
$$

\section{Results and discussion}

\subsection{Preliminary tests}

Preliminary examinations on the natural soil showed that the reddish-brown lateritic soil had $11.3 \%$ moisture content. The soil is categorized as A-4(2) [24] and SC [25]. A few of the natural soil properties are displayed in Table 1. The particle curve of the natural soil is revealed in Figure 3. 
Table 1. Natural soil properties

\begin{tabular}{|c|c|}
\hline Property & Quantity \\
\hline Percentage Passing No. 200 Sieve & 35.4 \\
\hline Liquid Limit, \% & 37.5 \\
\hline Plastic Limit, \% & 19.3 \\
\hline Plasticity Index, \% & 18.2 \\
\hline AASHTO Classification & $A-4(2)$ \\
\hline USCS & $\mathrm{SC}$ \\
\hline \multicolumn{2}{|l|}{ Maximum Dry Density, $\mathrm{Mg} / \mathrm{m}^{3}$} \\
\hline RBSL & 1.76 \\
\hline BSL & 1.83 \\
\hline WAS & 1.86 \\
\hline BSH & 1.9 \\
\hline \multicolumn{2}{|l|}{ Optimum Moisture Content, \% } \\
\hline RBSL & 16.2 \\
\hline BSL & 15.3 \\
\hline WAS & 14.5 \\
\hline BSH & 13.8 \\
\hline Colour & Reddish brown \\
\hline Dominant Clay Mineral & Kaolinite \\
\hline
\end{tabular}

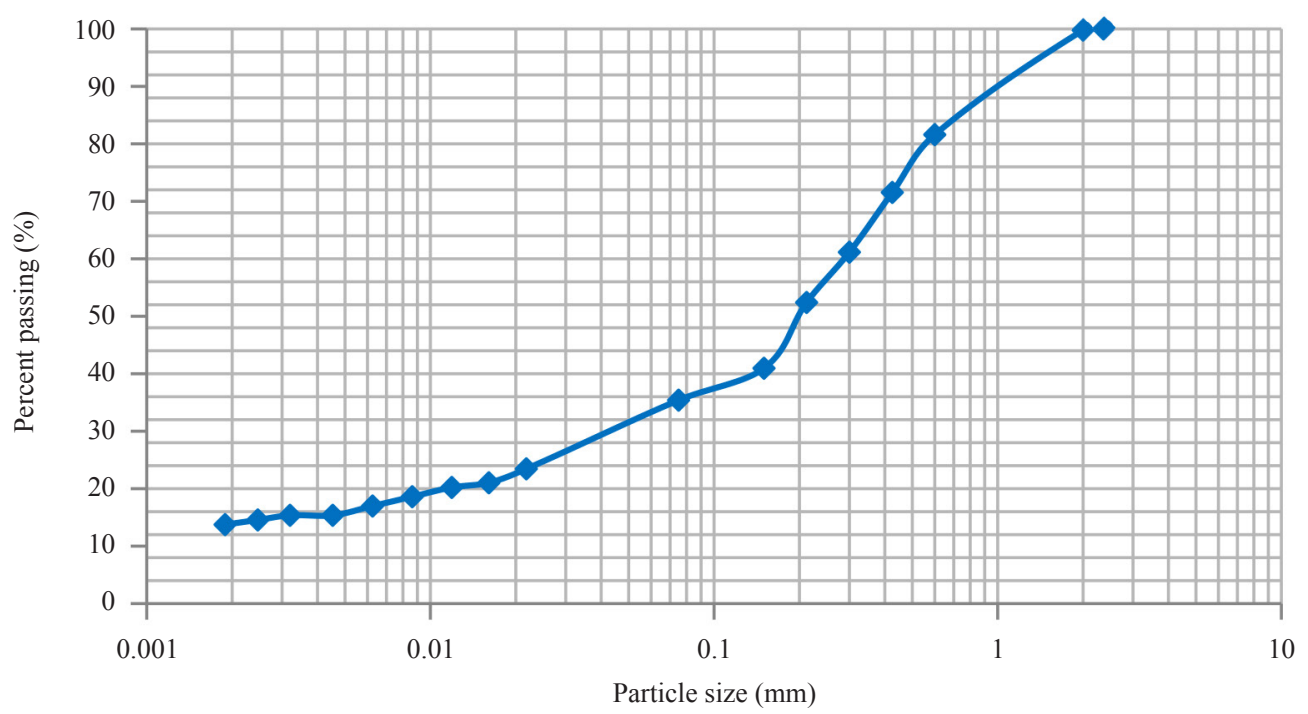

Figure 3. Particle curve of natural soil 


\subsection{Unconfined compressive strength}

\subsubsection{Effect of number of microbes}

Daniel and $\mathrm{Wu}$ [26] suggested a subjective small value of $200 \mathrm{kN} / \mathrm{m}^{2}$ as UCS of compacted soil to be used as liner and cover to sustain the bearing pressure in the landfill. Changes in UCS with varying numbers of microbes are shown in Figures 4a-d. Generally, an increase in UCS was noted with a corresponding increase in the number of microbes from 204.6, 278.3, 351.3, and $416.8 \mathrm{kN} / \mathrm{m}^{2}$ for the natural lateritic soil to the highest values of $1,036.3$, $1,835.5,2,076.8$, and $2,237.3 \mathrm{kN} / \mathrm{m}^{2}$ for specimens measured at OMC-2 and compacted with RBSL, BSL, WAS, and $\mathrm{BSH}$, respectively. Similar trends were observed for specimens measured at $0 \mathrm{OMC},+2 \% \mathrm{OMC}$, and $+4 \% \mathrm{OMC}$, respectively. The progressive increase in UCS values can be attributed to the increment in the number of microbes that perhaps expedited the precipitation of more quantities of CCC as a product of hydrolysis of urea [27]. Mass of calcite formed expedited clogging of pore spaces via bio-cementation. Similar conclusions were described by Abo-El-Enein et al. [27], Tsukamoto et al. [28], Cheng et al. [29], and Rowshanbakhta et al. [5]. From the recorded results, it is clear that compaction density has a great effect on the soil UCS. This suggests that BSH energy which gave the highest strength values is more reliable in achieving the desired density and strength in the field than the lower compaction energies, i.e., (RBSL $<$ BSL $<$ WAS $<$ BSH). Thus field compaction using smooth or sheep foot roller for a containment system should be measured based on the MWC of BSH to achieve the desired density and strength of the compacted soil.
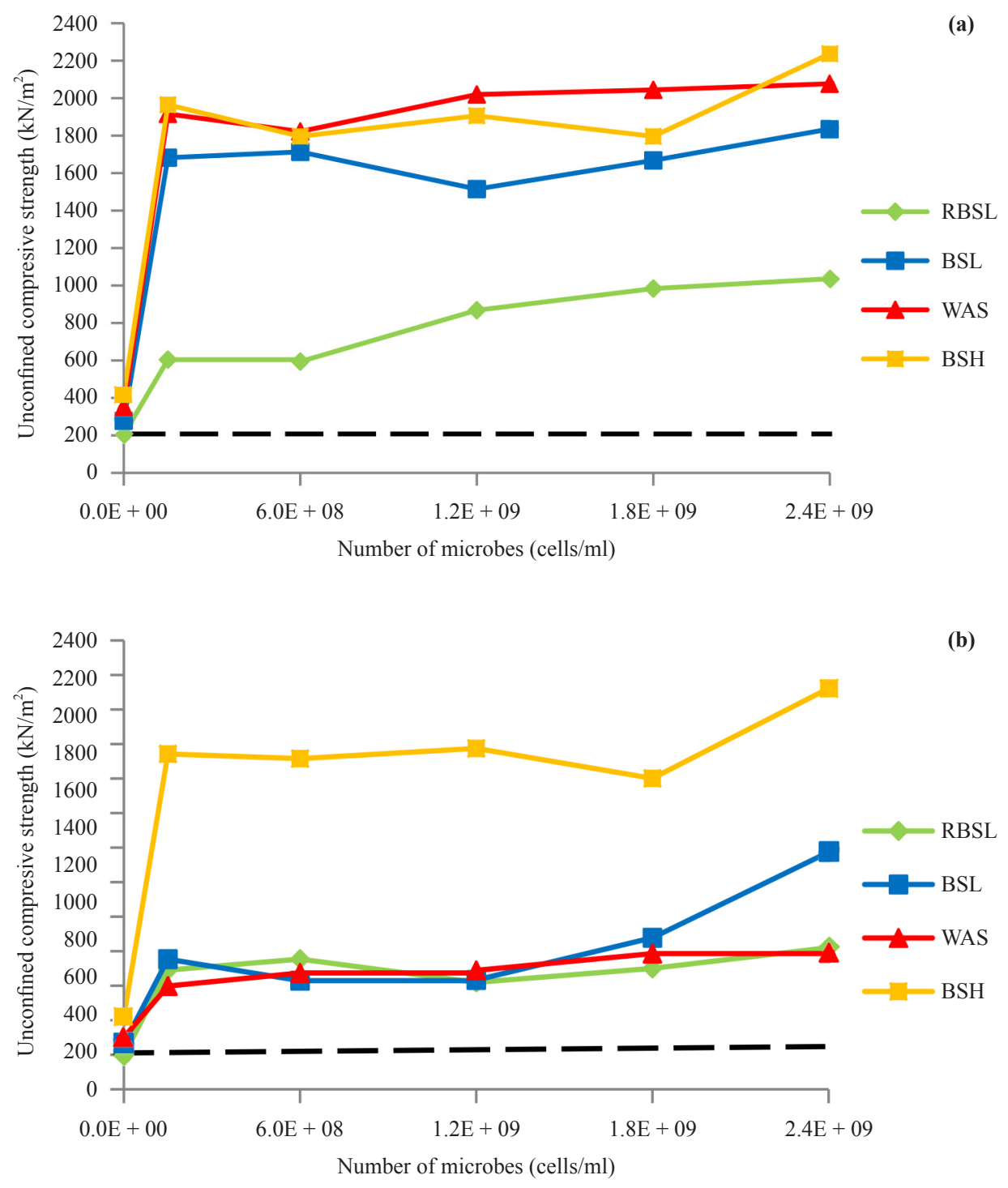

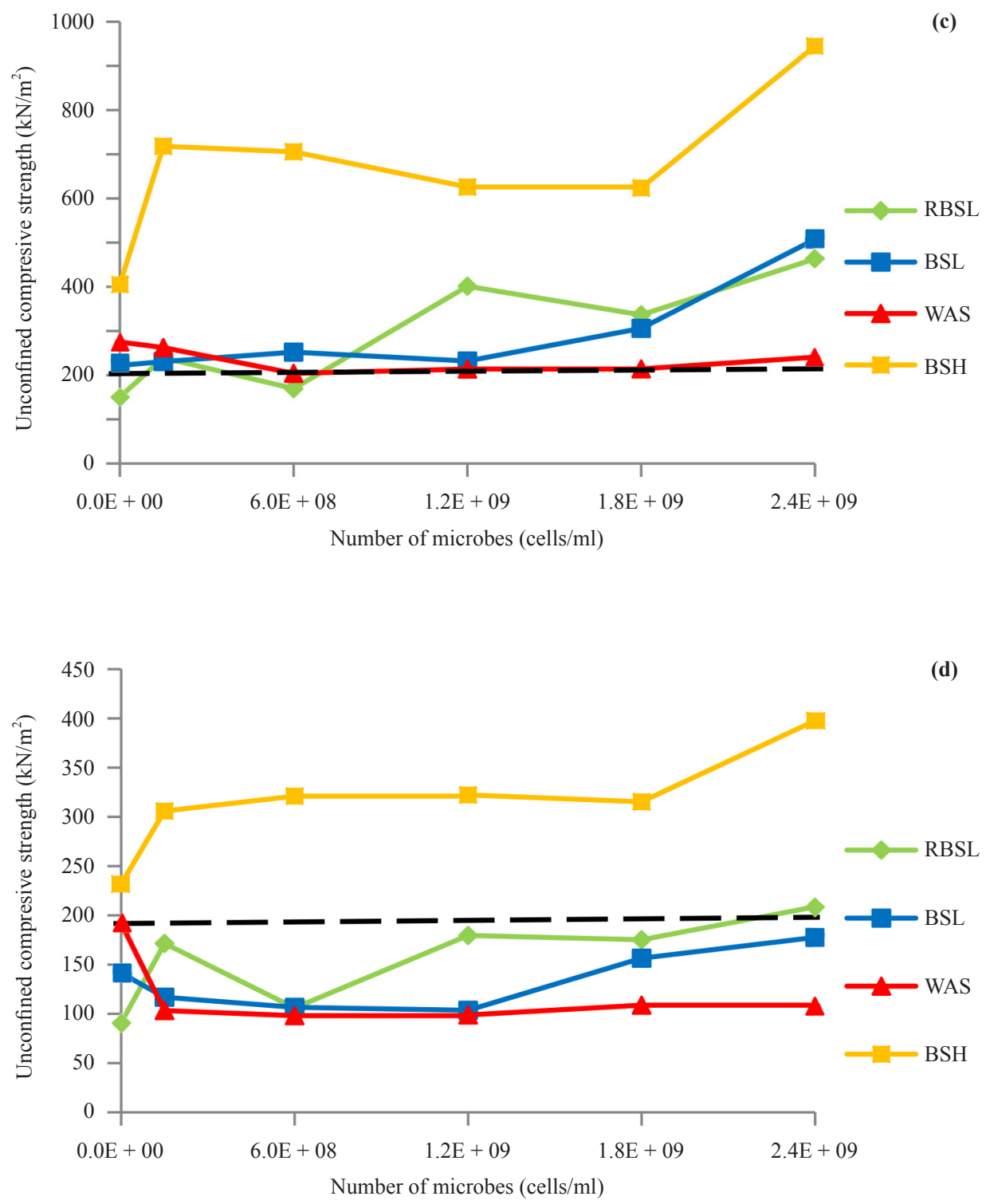

Figure 4. Variation of UCS of lateritic soil with number of microbes for specimens prepared at: (a) $-2 \%$ OMC (b) 0 OMC (c) $+2 \%$ OMC (d) $+4 \%$ $\mathrm{OMC}$

\subsubsection{Effect of MWC relative to OMC}

A graphical connection between UCS and MWC is shown in Figures 5a-f. The UCS values generally decreased with increased MWC. Similar findings were made by Daniel and Wu [26], Kabir and Taha [30], Osinubi et al. [31], Amadi [32], Oluremi [33], and Moses and Afolayan [34]. The UCS values rise with higher CE due to the reduction in pore size distribution in the soil that was expedited by the densification of soil. Related developments were reported by other researches [26], [35]. The UCS values of the natural soil compacted on at the dry side of OMC are 204.6, 278.3, 351.3 , and $416.8 \mathrm{kN} / \mathrm{m}^{2}$ for RBSL, BSL, WAS and BSH compaction, in that order (see Figure 5a). The UCS values decreased to $90.8,141.5,191.9$, and $231.9 \mathrm{kN} / \mathrm{m}^{2}$ for specimens prepared at $+4 \%$ OMC and compacted using RBSL, BSL, WAS, and BSH energy, respectively (see Figure 5a).

Similar trends were documented for specimens mixed with a variable number of microbes and prepared at MWCs of $0,+2$, and $+4 \%$ in relation to OMC. The continuous strength increase with increased CE may perhaps be credited to densification and bio-clogging of voids in the soil by the microbes. Also, soil stiffening which is linked to bio- 
cementation may perhaps be responsible for the increasing relative density and hence the UCS of the modified soil [5], [28], [29], [36].

Satisfactory results (i.e UCS $\geq 200 \mathrm{kN} / \mathrm{m}^{2}$ ) were documented for natural soil prepared at MWC in the ranges of $14.2 \%, 13.3-17.3 \%, 12.5-16.5 \%$, and $11.8-17.8 \%$ and compacted with RBSL, BSL, WAS, and BSH energy, in that order (see Figure 5a). Also, satisfactory UCS values were recorded at optimal $2.4 \times 10^{9}$ cells $/ \mathrm{ml}$ for samples prepared at MWC in the range of 14.2-18.2\%, 13.3-17.3\%, 12.5-16.5\%, and 11.8-17.8\% for RBSL, BSL, WAS, and BSH energy, correspondingly (see Figure 5f). Results show that a wider range of MWC of 11.8-17.8\% was attained at BSH than all the other energies, followed by WAS then BSL and RBSL. The implication of these results can note the fact that compaction of the soil using MWC of BSH can easily be achieved than the others and gives better strength. Although cost implications cannot be ruled out as heavier compaction equipment and a higher number of passes may be required to achieve BSH compaction in the field.
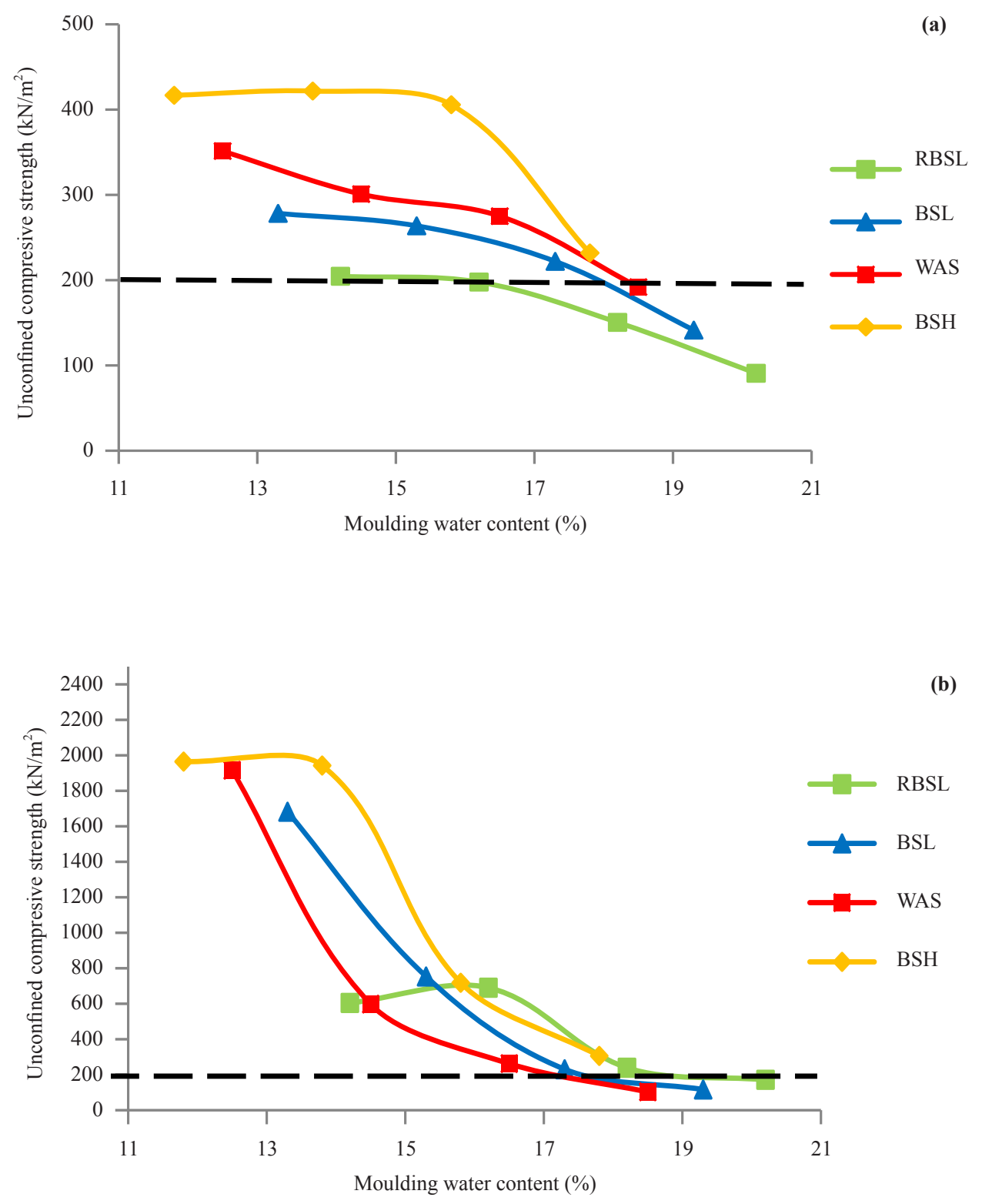

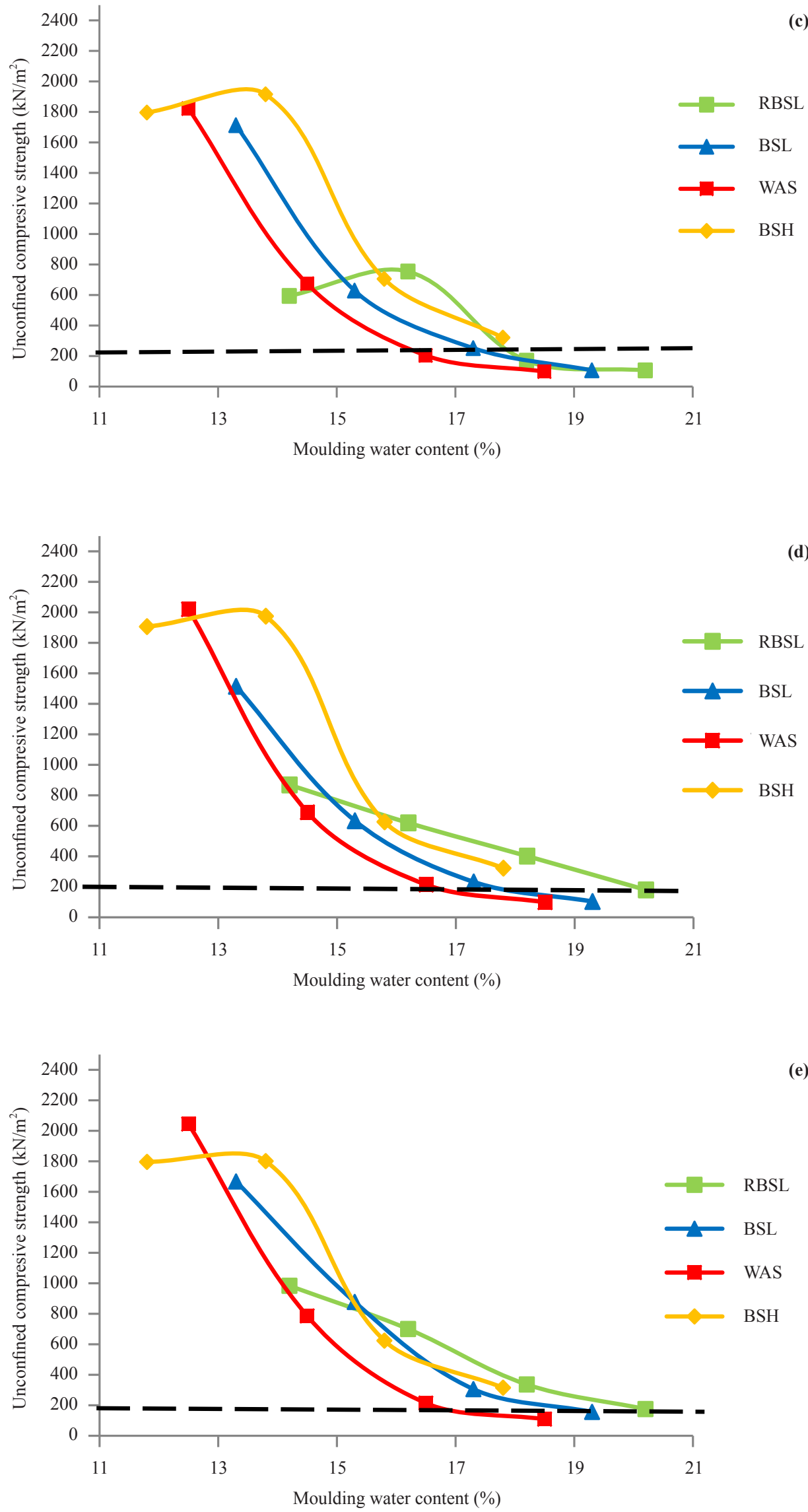


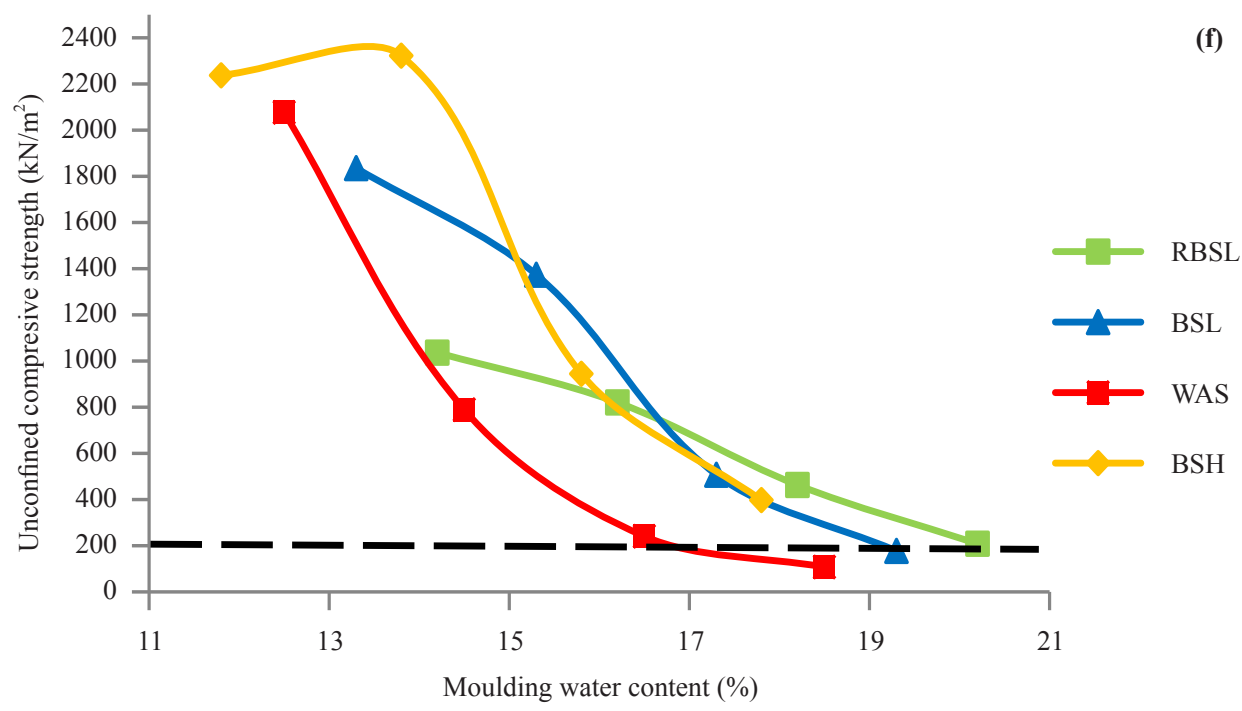

Figure 5. Plot of UCS of lateritic soil-number of microbes with MWC for: (a) Natural soil (b) $1.5 \times 10^{8} \mathrm{cells} / \mathrm{ml}$ (c) $6.0 \times 10^{8}$ cells $/ \mathrm{ml}$ (d) $1.2 \times 10^{9}$ cells $/ \mathrm{ml}(\mathrm{e}) 1.8 \times 10^{9}$ cells $/ \mathrm{ml}$ (f) $2.4 \times 10^{9}$ cells $/ \mathrm{ml}$

\subsubsection{Effect of CCC relative to UCS}

The variation of UCS with CCC is shown in Figure 6. Results show a general trend of increase in the UCS values with an increase in CCC. The increase in UCS could be due to the increase in the formation of $\mathrm{CaCO}_{3}$ which may not be unconnected to the increase in the number of nucleation sites. Similar findings were reported in pieces of literature [4], [6], [37].

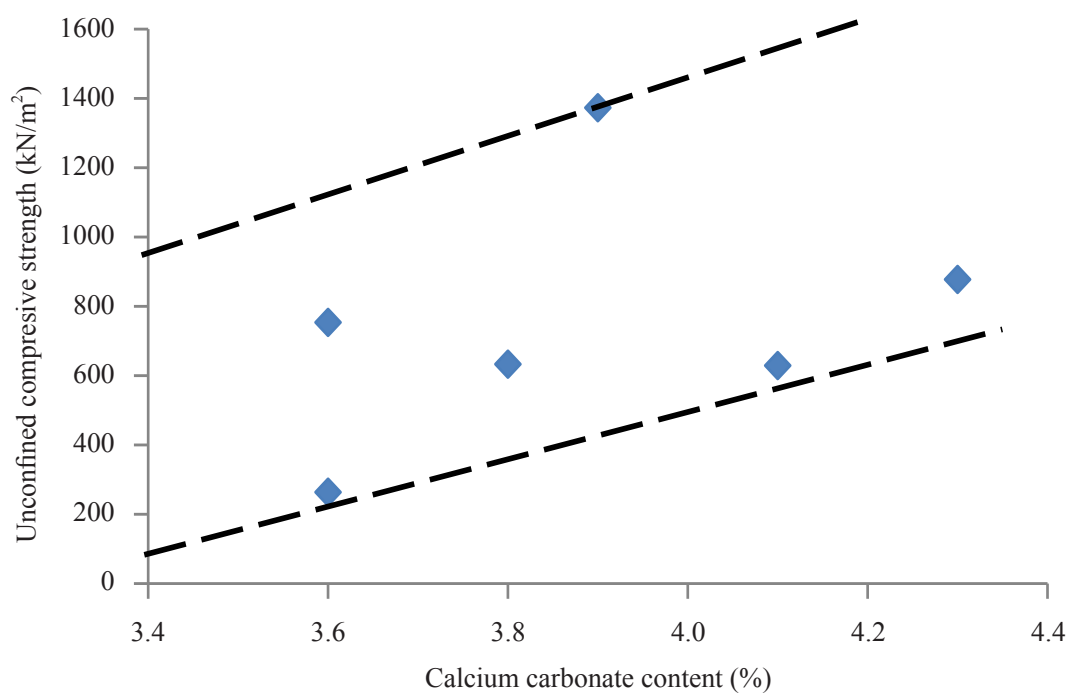

Figure 6. Plot of UCS against calcium carbonate content for BSL compaction at OMC

Statistical examination of the test results with the aid of analysis of variance for UCS is presented in Table 2. The results show the impact of the number of microbes and CE on the UCS are significant $\left(\mathrm{F}_{\mathrm{CAL}}=7.2690>\mathrm{F}_{\mathrm{CRIT}}=2.9013\right)$ for the number of microbes and $\left(\mathrm{F}_{\mathrm{CAL}}=26.3504>\mathrm{F}_{\mathrm{CRIT}}=3.2874\right)$ for $\mathrm{CE}$. The influence of CE was more noticeable than 
that of the number of microbes.

Table 2. Analysis of variance for UCS with number of microbes

\begin{tabular}{ccccccc}
\hline Property & Basis for Variation & Level of Freedom & $\mathrm{F}_{\mathrm{CAL}}$ & $\mathrm{p}$-value & $\mathrm{F}_{\mathrm{CRIT}}$ & \multicolumn{2}{c}{ Comment } \\
\hline $\begin{array}{c}\text { Unconfined } \\
\text { compressive } \\
\text { strength }\end{array}$ & number of microbes & 5 & 7.2690 & 0.0012 & 2.9013 & $\mathrm{~F}_{\mathrm{CAL}}>\mathrm{F}_{\mathrm{CRIT}}, \mathrm{SS}$ \\
\hline
\end{tabular}

SS = Significant effect

\section{$3.3 \mathrm{pH}$}

$\mathrm{pH}$ is a vital factor in MICP process as it greatly affects the performance of the microbes and even the calcite produced as the end product of MICP. The effect of number of microbes on the $\mathrm{pH}$ of the treated soil is revealed in Figure 7. There is a trend of increase in $\mathrm{pH}$ from its natural value of 5.97 to a maximum value of 7.85 at $1.2 \times 10^{9}$ cells/ $\mathrm{ml}$ and then declined to 6.65 at $2.4 \times 10^{9}$ cells $/ \mathrm{ml}$ for specimen sampled from the top. In the case of specimen sampled from the bottom, the $\mathrm{pH}$ first increased from its natural value of 5.97 to a maximum value of 7.23 at $1.5 \times 10^{8}$ cells $/ \mathrm{ml}$ and then declined to 5.86 at $2.4 \times 10^{9}$ cells $/ \mathrm{ml}$. However, Stocks-Fischer et al. [20] experimental work suggested that the $\mathrm{pH}$ of soil modified with microbes significantly influences the urease activities in soils and they also described a $\mathrm{pH}$ range of 6.0-8.0 for optimal urease activities and calcite formation. Furthermore, it was noticed that the $\mathrm{pH}$ values for both top and bottom for the optimally treated soil at $2.4 \times 10^{9}$ cells $/ \mathrm{ml}$ falls within the range recommended by StocksFischer et al. [20]. Several pieces of literature [12], [38]-[41] reported that $\mathrm{pH}$ affects MICP processes and reported optimal $\mathrm{pH}$ for calcite formation using different microorganisms.

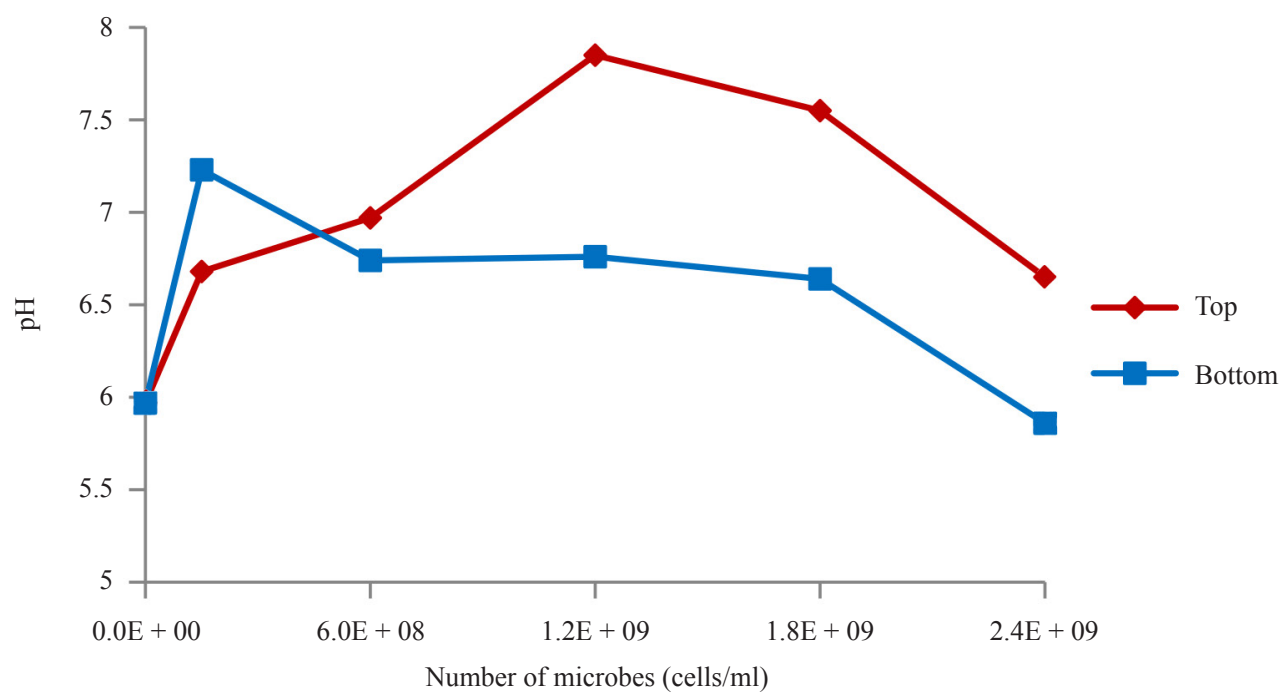

Figure 7. Plot of $\mathrm{pH}$ with the number of microbes (cells/ml)

\subsection{Calcium carbonate content test}

A result of calcium carbonate content (CCC) test is shown in Figure 8. The CCC inside the soil matrix structure 
increased with increment in the number of microbes beginning from 0 cells $/ \mathrm{ml}$ up to $2.4 \times 10^{9}$ cells $/ \mathrm{ml}$. Values marginally rise from 3.6 to $3.9 \%$. The increase may be connected with the produced urease enzymes by the microbes. Also, with the increment in microbe's population, it is supposed that more urease enzymes are released by the microbes leading to increased CC formation. Chi et al. [11] and Osinubi et al. [4] in there researches reported that increased bacteria density resulted in bigger enzyme actions, for the reason that the microbes' surfaces act as nucleation sites which tend to encourage calcite precipitation. $\mathrm{pH}$ and CCC play a vital role in determining the level of success in soil improvement using this MICP approach [12], [13].

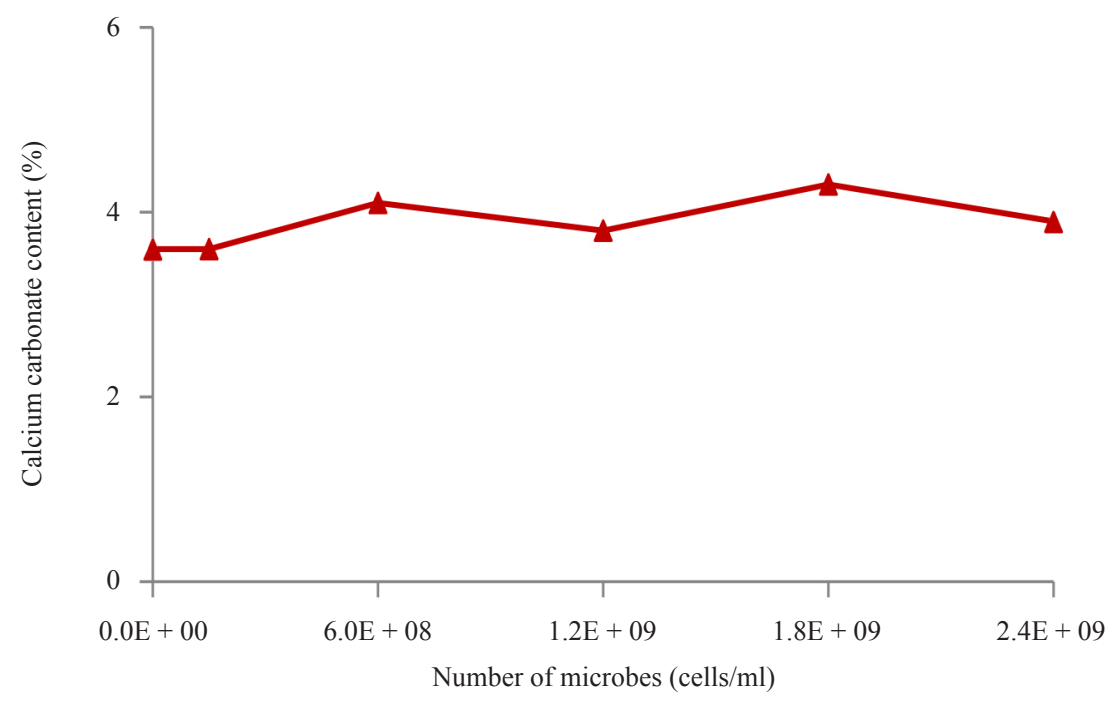

Figure 8. Plot of CC content with a varying number of microbes

\section{Conclusion}

The effect of the number of microbes and MWC on the UCS of lateritic soil for use as waste containment material was studied. Summary of the test results revealed an increase in $\mathrm{pH}$, from its natural value of 5.97 to a maximum value of 7.85 at $1.2 \times 10^{9}$ cells $/ \mathrm{ml}$ and then declined to 6.65 at $2.4 \times 10^{9}$ cells $/ \mathrm{ml}$ for specimen sampled from the top and a similar trend was observed for the bottom sample. Calcium carbonate content values marginally increased. The UCS values of lateritic soil increased with a higher number of microbes and lessened with the increase in MWC. A similar trend was experimented with for $0,+2$, and $+4 \%$ in relation to OMC. Statistical examination of the test results revealed that the influence of compactive effort was more noticeable than that of $B$. coagulans suspension density on the improved soil. Minimum regulatory UCS value of $200 \mathrm{kN} / \mathrm{m}^{2}$ was achieved at MWC of $-2,0$, and $+2 \%$ for all the compactive energy. Therefore, it is recommended that CE, moisture content, and the number of microbes should be considered during the construction of a lateritic soil compacted clay liner in other to achieve the desired result. Also, field compaction for a containment system should be measured based on the MWC of BSH to achieve the desired results.

\section{Acknowledgment}

We wish to acknowledge the Department of Civil Engineering, Ahmadu Bello University, Zaria, Kaduna State, Nigeria that provided the platform to conduct this research. 


\section{Conflict of interest}

The authors declare that there is no personal or organizational conflict of interest with this work.

\section{References}

[1] M. Alhassan, and A. M. Mustapha, "Effect of rice husk ash on cement stabilized laterite," Leonardo Electronic Journal of Practices and Technologies, vol. 11, no. 11, pp. 47-58, 2007.

[2] R. K. Etim, I. C. Attah, and P. Yohanna, "Experimental study on potential of oyster shell ash in structural strength improvement of lateritic soil for road construction," International Journal of Pavement Research and Technology, vol. 13, no. 4, pp. 341-351, 2020. Available: https://doi.org/10.1007/s42947-020-0290-y.

[3] J. R. Oluremi, S. I. Adedokun, P. Yohanna, D. A. Fadiran, and I. O. Azeez, "Evaluation of compacted laterite soil admixed with cement and hair fibers as road construction material," Journal of Engineering Research, vol. 8, no.1, pp. 55-71, 2020.

[4] K. J. Osinubi, P. Yohanna, A. O. Eberemu, and T. S. Ijimdiya, "Unconfined compressive strength of lateritic soil treated with Bacillus Coagulans for use as liner and cover material in waste containment system," IOP Conference Series: Materials Science and Engineering, vol. 640, no.1, pp. 012081, 2019. Available: https://doi. org/10.1088/1757-899X/640/1/012081.

[5] K. Rowshanbakhta, M. Khamehchiyana, R. H. Sajedib, and M. R. Nikudela, Effect of injected bacterial suspension volume and relative density on carbonate precipitation resulting from microbial treatment," Journal of Ecological Engineering, vol. 89, pp. 49-55, 2016. Available: https://doi.org/10.1016/j.ecoleng.2016.01.010.

[6] K. J. Osinubi, A. O. Eberemu, T. S. Ijimdiya, S. E. Yakubu, E. W. Gadzama, J. E. Sani, and P. Yohanna, "Review of the use of microorganisms in geotechnical engineering application," SN Applied Sciences, vol. 2, no. 2, pp. 1-19, 2020. Available: https://doi.org/10.1007/s42452-020-1974-2.

[7] J. T. Dejong, C. Proto, M. Kuo, and M. Gomez, "Bacteria, bio-films and invertebrates: The next generation of geotechnical engineers," Proceedings of geo-congress 2014: Geo-characterization and Modeling for Sustainability, vol. 234, pp. 3959-3968, 2014.

[8] A. J. Smith, P. Martin, E. Alan, and B. Shafakat, "The reduction of the permeability of a lateritic soil through the application of microbially induced calcite precipitation," Natural Resources, vol. 8, no. 5, pp. 337-352, 2017.

[9] M. Donovan, A. S. Mohamed, and C. Liang, "State-of-the-art review of biocementation by microbially induced calcite precipitation (MICP) for soil stabilization," Geomicrobiology Journal, vol. 34, no. 6, pp. 524-537, 2017. Available: https://doi.org/10.1080/01490451.2016.1225866.

[10] V. Rejash, and M. Venugopal, “A study on mechanical properties of bacterial concrete using fly ash and foundry sand," i-Manager's Journal on Civil Engineering, vol. 7, no. 2, pp. 20-26, 2017.

[11] C. Li, D. Yao, S. H. Liu, T. J. Zhao, S. Bai, Y. Gao, and L. Li, "Improvement of geomechanical properties of bioremediated aeolian sand," Geomicrobiology Journal, vol. 35, no. 2, pp. 132-140, 2017. Available: https://doi.org/1 0.1080/01490451.2017.1338798.

[12] A. Rajasekar, C. K. S. Moy, and S. Wilkinson, "MICP and advances towards eco-friendly and economical applications," IOP Conference Series: Earth and Environmental Science, vol. 78, no. 1, pp. $012016,2016$. Available: https://doi.org/10.1088/1755-1315/78/1/012016.

[13] V. Ivanov, and J. Chu, "Applications of microorganisms to geotechnical engineering for bioclogging and biocementation of soil in situ," Reviews in Environmental Science and Bio/Technology, vol. 7, no. 2, pp. 139-153, 2008.

[14] C. Fang, J. He, V. Achal, and G. Plaza, "Tofu wastewater as efficient nutritional source in biocementation for improved mechanical strength of cement Mortal," Geomicrobiology Journal, vol. 36, no. 6, pp. 515-521, 2019. Available: https://doi.org/10.1080/01490451.2019.1576804.

[15] M. J. Castro-Alonso, L. E. Montañez-Hernandez, M. A. Sanchez-Muñoz, M. R. Macias Franco, R. Narayanasamy, and N. Balagurusamy, "Microbially induced calcium carbonate precipitation (MICP) and its potential in bioconcrete: Microbiological and molecular concepts," Frontier Materials, vol. 6, pp. 126, 2019. Available: https:// doi.org/10.3389/fmats.2019.00126.

[16] K. L. Tian, X. D. Wang, S. C. Zhang, H. L. Zhang, F. Zhang, and A. Q. Yang, "Effect of reactant injection rate on solidifying aeolian sand via microbially induced calcite precipitation," Journal of Materials in Civil Engineering, vol. 32, no. 10, pp. 4020291, 2020. Available: https://doi.org/10.1061/(ASCE)MT.1943-5533.0003391. 
[17] J. E. Sani, G. Moses, and F. O. P. Oriola, "Evaluating the electrical resistivity of microbial-induced calcite precipitate-treated lateritic soil," SN Applied Science, vol. 2, no. 9, pp. 1-12, 2020. Available: https://doi. org/10.1007/s42452-020-03285-x.

[18] J. E. Sani, G. Moses, and F. O. P. Oriola, "Effects of curing time and compactive effort on unconfined compressive strength test of Microbial induced calcite precipitate treated lateritic soil," Federal University Wukari Trends in Science and Technology Journal, vol. 5, no. 3. pp. 642-648, 2020.

[19] ATCC, American type culture collection. P. O Box 1549 Manassas, VA 20108 USA, 2013. Available: http://www. atcc.org.

[20] S. Stocks-Fischer, J. K. Galinat, and S. S. Bang, "Microbiological precipitation of CaCO 3 " Soil Biology and Biochemistry, vol. 31, no. 11, pp. 1563-1571, 1999.

[21] J. Jeffery, BS1377 methods of test for soils for civil engineering purposes. British Standard Institute, BSI, London, 2018.

[22] B. M. Mortensen, M. J. Haber, J. T. DeJong, L. F. Caslake, and D. C. Nelson, "Effects of environmental factors on microbial induced calcium carbonate precipitation," Journal of Applied Microbiology, vol. 111, no. 2, pp. 338-349, 2011. Available: https://doi.org/10.1111/j.1365-2672.2011.05065.x.

[23] S. G. Choi, S. S. Park, S. Wu, and J. Chu. "Methods for calcium carbonate content measurement of biocemented soils," Journal of Materials in Civil Engineering, vol. 29, no. 11, pp. 06017015, 2017.

[24] AASHTO, Standard specification for transportation, material and methods of sampling and testing. Amsterdam Association of State Highway and transportation officia Washington D.C., 1986.

[25] ASTM, Annual book of standards. American Society for Testing and Materials. Philadelphia, 1992.

[26] D. E. Daniel, and Y. K. Wu, "Compacted clay liners and covers for arid sites," Journal of Geotechnical Engineering, vol. 119, no. 2, pp. 223-237, 1993.

[27] S. A. Abo-El-Enein, A. H. Ali, F. N. Talkhan, and H. A. Abdel-Gawwad, "Utilization of microbial induced calcite precipitation for sand consolidation and mortar crack remediation," Journal of Housing and Building National Research Center, vol. 8, no. 3, pp. 185-192, 2012.

[28] M. Tsukamoto, T. Inagaki, Y. Sasaki, and K. Oda, "Influence of relative density on microbial carbonate precipitation and mechanical properties of sand," in Proceedings of the 18th International Conference on Soil Mechanics and Geotechnical Engineering, 2013, pp. 2613-2616.

[29] L. Cheng, M. A. Shahin, R. Cord-Ruwisch, M. Addis, T. Hartanto, and C. Elms, "Soil stabilization by microbial induced calcium carbonate precipitation: Investigation of some important physical and environmental aspects," in 7th International Congress on Environmental Geotechnics, 10-14 November, Melbourne, Australia, 2014.

[30] M. H. Kabir, and M. R. Taha, "Assessment of physical properties of a granite residual soil as an isolation barrier," Electronic Journal of Geotechnical Engineering, vol. 92, no. c, pp. 13, 2004.

[31] K. J. Osinubi, A. O. Eberemu, and A. A. Amadi, "Compacted lateritic soil treated with blast furnace slag as hydraulic barrier in waste containment systems," International Journal of Risk Assessment and Management, vol. 13, no. 2, pp. 171-189, 2009.

[32] A. A. Amadi, "Hydraulic and contaminant transport performance of compacted lateritic soil-bentonite mixtures proposed as waste containment barrier," Unpublished Ph.D. dissertation submitted to the Department of Civil Engineering, Ahmadu Bello University, Zaria, 2008.

[33] J. R. Oluremi, "Evaluation of waste wood ash treated lateritic soil for use in municipal solid waste containment application," Unpublished Ph.D Thesis. Department of Civil Engineeering Ahmadu Bello University Zaria, 2015.

[34] G. Moses, and J. O. Afolayan, "Compacted foundry sand treated with cement kiln dust as hydraulic barrier material," Electronic Journal of Geotechnical Engineering, vol. 16, pp. 337-355, 2011.

[35] K. J. Osinubi, and C. M. O. Nwaiwu, "Design of compacted lateritic soil liners and covers," Journal of Geotechnical and Geoenvironental Engineering, vol. 132, no. 2, pp. 203-213, 2006.

[36] W. S. Ng, M. L. Lee, and S. L. Hii, "An overview of the factors affecting microbial-induced calcite precipitation and its potential application in soil improvement," World Academy of Science, Engineering and Technology, vol. 6, no. 2, pp. 683-689, 2012.

[37] M. U. Zango, K. A. Kassim, A. S. Muhammed, K. Ahmad, and J. Makinda, "Effect of biocementation via enzymatic induced calcium carbonate precipitation (EICP) on the shear strength of compacted clay liner," IOP Conference. Series: Materials Science and Engineering, vol. 1153, no. 1, pp. 012008, 2021. Available: https://doi. org/10.1088/1757-899X/1153/1/012008.

[38] H. L. Mobley, M. D. Island, and R. P. Hausinger, "Molecular biology of microbial ureases," Microbiological Reviews, vol. 59, no. 3, pp. 451-480, 1995.

[39] Y. Fujita, G. D. Redden, J. C. Ingram, M. M. Cortez, F. G. Ferris, and R. W. Smith, "Strontium incorporation into 
calcite generated by bacterial ureolysis," Geochimica et Cosmochimica Acta, vol. 68, no. 15, pp. 3261-3270, 2004.

[40] M. Umar, K. A. Kassim, and K. T. P. Chiet, "Biological process of soil improvement in civil engineering: A review," Journal of Rock Mechanics and Geotechnical Engineering, vol. 8, no. 5, pp. 767-774, 2016.

[41] A. S. Muhammed, K. A. Kassim, and M. U. Zango, "Review on biological process of soil improvement in the mitigation of liquefaction in sandy soil," MATEC Web of Conferences, vol. 250, no. 4, pp. 01017, 2018. Available: https://doi.org/10.1051/matecconf/201825001017. 